\title{
Research on the Optimization of the Value of Intangible Assets for the Products Design Company
}

\author{
Bo LI*, Rui-cong WU \\ Faculty of Art and Design, Xi'an University of Technology, Xi'an, Shaanxi, China \\ ${ }^{*}$ Corresponding author
}

\begin{abstract}
Keywords: Value of Intangible Assets; Value Optimization; Products Design Company.
\end{abstract}
\begin{abstract}
In order to seek for a scientific method to optimize the value of intangible assets of Product Design Company, based on the analysis of the characteristics and the status and role of the intangible assets, the value evaluation index is also clarified. Paper studied the value evaluation model of intangible assets for the products design company. Research shows that this method can increase the speed and extent of invisible knowledge accumulation in human capital, and through commercial structural capital to improve the value of intellectual assets and achieve its commercialization process quickly.
\end{abstract}

\section{Introduction}

Product design is the core of industrial design, and the key link in the use of design for enterprises because it changes the form of raw materials into a more valuable form. Under the background of global economic integration, the development mode of low cost of human resources which depends on natural resources has changes into a new innovative form which relies on the creativity to obtain competitive advantage. People realize that though reduce the cost of production is important, the design to improve the value is more vital. Finally, the development of the economy is bound to design products through cultural infiltration to enhance the value-added of the product. The creativity and commercialization of economic, social and cultural development, relying on human original power, has formed of the creative industry [1]. For the time being, the most important driving force in China's creative industry is industrial design. Most scholars believe that the competitive advantage of the industrial design industry is usually related to the intellectual capital and intangible assets that they have inside. Therefore, it is of great significance to study the composition and value optimization of the intangible assets for the Products Design Company.

\section{The Status and Role of the Intangible Assets in the Products Design Company}

Intangible assets are assets that can create value for the company in addition to the tangible assets of a company, which is called intellectual capital. In 1969, Galbraith, a related scholar, put forward the concept of intellectual capital for the first time [2]. He pointed out that intellectual capital is a kind of knowledge activity, a dynamic capital rather than a fixed capital form. Intellectual capital includes knowledge not only reflecting and recognizing objective things, but also the ability to perceive the future. At the same time, the influence of external environment on business strategy is also considered. In the operational management of enterprises, enterprise intellectual capital concept advocates the view combined with the external environment and enterprise resource view, analysis of the current situation of enterprises, so as to obtain the core competence for enterprises to obtain competitive advantage, thus forming a sustainable competitive advantage to provide theoretical support.

Thomas Stewart, a relevant scholar, is the first scholar to systematically explain the meaning of intellectual capital. He thinks that intellectual capital refers to the sum of all the knowledge and abilities that each person and team can bring to the company's competitive advantage. All knowledge, consultation, technology, intellectual property, experience, organizational learning ability, team communication mechanism, customer relationship and brand status that can be used to create wealth 
belong to the composition of intellectual capital.

Intangible assets can be generally obtained through three ways: self creation, outsourcing and shareholder input. The acquisition of intangible assets of Products Design Company is usually achieved by self created way. The good foundation of the intangible assets is the good historical performance of the company, the exquisite technical level of the designers and the high quality talent team. These intangible assets are all attached to the professional and technical backbone and management personnel at all levels of the company. If these backbone drain, no matter how brilliant the past, the value of intangible assets will depreciate or even run away.

The industrial design of our country is faced with the situation of competitiveness is not strong, outstanding performance for the intellectual property rights awareness is not enough, pay attention to tangible assets in the design industry, despise the intangible assets; pay attention to the traditional model of intangible assets, despise intangible assets; attach importance to the development of intangible assets, intangible assets management as light; the importance of intangible self increment, contempt of intangible assets stock.

The product company is a typical design driven, high value-added knowledge enterprise [3]. The domestic product design industry generally recognized the importance of new technology update. However, due to various factors, the frequency of upgrading or buying computers or software is not high, most of which are changed every $3 \sim 5$ years. The new technology is very important for the product design industry, which is related to the rapid occupation of the market by its services and related products.

In the past, most of the research on intangible assets was based on modeling enterprises, and little attention was paid to the intangible assets of service industry. Most of them were found in the service sector. This also indirectly proves why the input and output of service industry is difficult to measure, because the productivity of the service industry is mainly from the investment of intangible assets. Second, taking into account the characteristics of the service industry, it is difficult to assess the intangible assets of the service industry. There are a wide variety of sub industries under the service industry, with a productive service industry and a traditional service industry. Different sub industries, there are great differences in the research of intangible assets, and no more standards are extracted, so the research on intangible assets in service industry is lack.

\section{The Analysis of the Characteristics of the Intangible Assets of the Products Design Company}

Based on the definition of intellectual capital and the comparison of scope of study in the world, according to the evolution of time, we conclude that intellectual capital involves of human capital, structural capital, customer capital, innovative capital and process capital. Therefore, the company's intangible assets equivalent to the company's intellectual capital, anything that can increase or create added value for the company such as talents, technology, knowledge, creativity, experience, operation system, organization structure, external influence and customer relations, all belong to the scopes.

\subsection{The Composition of the Intangible Assets in the Products Design Company}

Firstly, it is the rights type intangible assets. It refers to the intangible assets generated by Products Design Company in written or non written contract terms, including unit qualification, long-term contracts, etc. Second, relational intangible assets are usually non contractual, but they have great value for Company, including stable customer relationship, collaborative relationship between design enterprises, industry associations and government departments. The third is the intangible assets of intellectual property, which are usually protected by law and are not allowed to be used without authorization. Such intangible assets include: patent technology and know-how acquired by Products Design Company, such as new technology, new structure and application and development of new materials; the copyright of the design drawings of the product design, the independent development of computer software, design report, technical standard, specification and other publications, etc; proprietary technology, copyright, design drawings, etc. They are very important for the design 
company, but the protection is not enough for a long time. The fourth is the combination of intangible assets, mainly including: the reputation of the industry, the reputation of the design of enterprises, trademarks and so on. Generally, enterprises have their own trademarks, which is one of the important contents of designing enterprises' intangible assets. However, few design companies register and protect their trademarks. The fifth is human resources intangible assets. Design companies belong to intelligence intensive enterprises. This part of intangible assets is finally reflected by the quality of its human assets.

\subsection{The Characteristics of the Intangible Assets of the Products Design Company}

The product design industry is a highly knowledge-based intellectual capital industry, which is highly competitive, rapid technological evolution and short life cycle, and the price of products is falling rapidly. In the design industry, its intangible assets have the following characteristics:

The value of intangible assets is timeliness: no matter how outstanding technology or intellectual property rights are, if they can't adapt to the trend of market, most of them can't play their due value.

There is a lag in the value of intangible assets in time: intangible assets are the leading indicators of profit. Therefore, once employees are trained to be employees of the company's professional experience, they become the assets of the company. The accumulation of customer relationship is an investment and a liability. Once applied successfully, it will become the intellectual capital that can create value for the company in the future.

The value of intangible assets is dependent on market supply and demand: the environment has a significant impact on the value of intangible assets, and the relationship between smart supply and smart demand determines the price of intangible assets. Only when the return of the enterprise to the market is greater than that of the previous technology input, this design is a valuable innovation; if the return is less than the input, it is a design without commercial value and is not suitable for investment.

The value of intangible assets is not only determined by the investment of research costs. In the market competition is often the "survival of the fittest", rather than "good" survival, big company is rich in resources, but technology development direction is too fragmented or too slow, resulting in no results. Small companies may have a great increase in corporate turnover because of the characteristics of some design skills or business innovation.

For design companies, intangible assets must be interconnected with the whole company's resources, execution, strategies and market pulsation, so as to create value [4]. The value of a company will not increase as a result of an increase in a single intangible asset. Managers and decision-makers must assess the situation of the intangible assets of an enterprise from a holistic perspective, not just a single intelligence measure.

\subsection{The Value Evaluation Index of the Products Design Company Intangible Assets}

The intangible assets of the Products Design Company are the most important quality assets, and the neglect of the intangible assets in the past makes the interests of the enterprises and individuals all the damage. In the process of product design, human capital occupies an important position and plays a decisive role in the formation of intellectual assets and the formation of intellectual capital.

Human capital refers to the knowledge and ability of the employees to solve customer problems, for the individual, no transfer of tacit knowledge and experience; intellectual assets are cured, visible or for a specific description of the physical properties of knowledge, are owned by the company, one of which is protected and commercial knowledge; capital structure is defined as the ability to transform human capital into intellectual assets and intellectual assets into corporate profits tangible and intangible capital, which includes commercial structural capital and intellectual structural capital .

Human capital refers to the knowledge and ability of the employees to solve customer problems, for the individual, no transfer of tacit knowledge and experience; intellectual assets are cured, visible or for a specific description of the physical properties of knowledge, are owned by the company, one of which is protected and commercial knowledge; capital structure is defined as the ability to 
transform human capital into intellectual assets and intellectual assets into corporate profits tangible and intangible capital, which includes commercial structural capital (tangible assets) and intellectual structural capital .

Business structural capital refers to the company can through all kinds of tangible capital market, such as finance, construction, computer and network system, all kinds of infrastructure such as the monetization of physical capital; intellectual structural capital is based on commercial structural capital as the foundation, formed by the human capital is the intangible capital to the company's value creation and acquisition. That is different to intellectual capital, can not be defined as the intellectual assets, structural capital but with intellectual property, it is a reflection of the use of economic resources of the company.

Structural capital plays a very important role in intellectual capital. The matching and efficiency of intellectual structural capital and human capital and commercial structural capital determine the benefit and value increment of both. In the process of the creation and application of intellectual assets, an effective intellectual structural capital will form a virtuous circle of intellectual capital value creation and acquisition.

\section{The Value Evaluation Model of Intangible Assets for the Products Design Company}

In traditional sense, the value driver of intangible assets is an additive concept. But from the perspective of Products Design Company, the evaluation of intangible assets is more difficult. An intangible asset is not only hard to evaluate, but also hard to create value independently. For example, a design company put more manpower and material resources into research, and then created more technology and skills. If a company has a lot of manpower and material resources can be developed to a very strong function of the product, but not in the market window period launched, or to customer requirements at the time node launched a commodity, then the goods can not meet the requirements of the function of the market, while the above two conditions can create value for the company at the same time. Only companies that can meet both functional requirements and product time nodes will win.

The momentum equation can be used to describe the ability of design company to creat value.[5],

Momentum $=$ Mass $\times$ Velocity

The ability of Design Company to create value is a directional vector, because the company's speed of providing unique technologies or services has its professional limits. Its direction is not necessarily the same as the target market, but the real momentum in the same direction with the target market is effective momentum, so momentum equation must be vector product with the direction of the target market.

The value function of intangible assets $=($ Mass $\times$ Speed $) \cdot$ Direction

Among them, quality represents the excellence of technology and service, as well as the accumulation of relevant talent strength and past experience. Quality can be defined as the ability to create market value for customers, suppliers, partners, employees, and investors. Must deal with three kinds of advantages relative to competitors and competition type: strong design ability than competitors; designed products and services to the end customer obvious income; product or service competition designed to imitate, or difficult for competitors to follow.

For speed, industrial design, especially product design, is mainly by speed, organization and enthusiasm, system and creativity are all the sufficient conditions for the creation of speed. How to build the most efficient and most professional organizational structure, how to establish a more effective standard of group behavior is very important. Everyone in the team needs to quickly debug with time and environment to complete a quick creative solution. Managers and designers of enterprises should keep their curiosity and observation on everything so that they can launch high value products and services faster than their competitors. For every direction, and the company's development strategy or orientation ability can be referred to as the direction, the so-called direction mainly refers to, firstly, understand their company's expertise and core competition ability; secondly, 
find the target market, to provide cash and profits enough to maintain the company's growth; thirdly, the Limited resources together to create the focusing effect.

According to the industry characteristics and value realization mode of Products Design Company, and following the principles of intangible assets value model of industrial design industry, we formulate relevant measurement indexes, which can evaluate the value characteristics and intangible assets evaluation methods of the industry company.

\section{Conclusion}

Through the analysis of the value model of intangible assets, the management of intangible assets is of great significance for the Products Design Company. Human capital occupies an important position and plays a decisive role in the formation of intellectual assets and the formation of intellectual capital. The creativity and application of human capital play a key role in the final formation of the intellectual capital of the design company. For the creation and management of intellectual assets, we should increase the speed and extent of invisible knowledge accumulation in human capital, improve the value of intellectual assets and achieve its commercialization process quickly, so as to benefit the formation of future visible profits. For the use of commercial structural capital, we should pay attention to its potential future income under the effect of intellectual capital.

With the advantages of natural resources and labor intensive, China has developed into a big manufacturing country. Many places have the capacity of large-scale manufacturing, which has laid a good foundation for further development, but the role of such a global manufacturing plant is also fatal. Because of Chinese manufacturing industry belongs to production and processing, in the product value chain "smile curve" arc bottom with low value-added products, and by foreign control of the industrial chain upstream and downstream research brand sales, the value-added income is often more than ten times the domestic processing enterprises or even a few hundred times. The only way to realize the growth pole of our country's economy is independent innovation. In the face of the huge manufacturing scale, the development of industrial design is an important way of independent innovation, an important way to realize the transformation from Chinese manufacture to Chinese creation, and an inevitable choice to realize industrial upgrading and structural adjustment.

\section{Acknowledgement}

This research was financially supported by Humanities and Social Sciences Project of Shaanxi Province Education Department (17JK0522) \& the Special Project on Humanities and Art of Xi'an University of Technology (106-451017004).

\section{References}

[1] Yao Tingting, Research on the cultural element of China's Industrial Design [D]. Changchun: Jilin University master thesis, 2007

[2] Masoulas \&Vasilis: Organization Requirements Definition for Intellectual Capital Management

[J]. International Journal of Technology Management, 1998, vol.16

[3] Yin Dingbang, Chen Hanqing, Shao Hong, Marketing and Management of Design [M]. Changsha: Hunan Science and Technology Press, 2003

[4] Sung-Sik Lee, Jaehwan Lee, Suk-Gill Jung, Young-Soon Park, Charn Moon: A Study on Design Industry Development Model of Korea in 2010 [J]. Geo Journal, 2010.5

[5] Zhang Li. Thinking of industrial design under the pattern of cultural and creative industries [J]. Science \& Technology Progress and Policy, 2007.08 